\title{
PENINGKATAN KEMAMPUAN GERAK MANIPULATIF MELALUI PERMAINAN BOWLING BOTOL
}

\author{
Alawiyah Rahmah ${ }^{1}$, Yasbiati $^{2}$, Lutfi Nur ${ }^{3}$, Ervan Kastrena ${ }^{4}$ \\ ${ }^{1-3}$ Program Studi PGPAUD UPI Kampus Tasikmalaya, Indonesia \\ ${ }^{4}$ Program Studi PJKR Universitas Suryakancana Cianjur, Indonesia \\ E-mail : hurirahma22@gmail.com ervankastrena@unsur.ac.id, Lutfinur@upi.edu
}

\begin{tabular}{l}
\hline Info Artikel \\
\hline Sejarah Artikel: \\
Diterima Maret 2019 \\
Disetujui April 2019 \\
Dipublikasikan Juni 2019
\end{tabular}

\begin{abstract}
Abstrak
Penelitian ini dilatarbelakangi oleh pentingnya kemampuan gerak manipulatif anak usia dini, dengan permasalahan yang muncul yaitu kemampuan gerak manipulatif yang belum optimal pada anak kelompok A di RA Al Istiqomah Kota Tasikmalaya. Dalam pembelajaran motorik kasar terutama dalam gerak manipulatif di PAUD, permainan yang digunakan yaitu menangkap dan melempar bola dilakukan berulang-ulang. Hal ini ditunjukan dengan indikator kemampuan gerak manipulatif anak dalam melempar dan menangkap bola yang masih rendah. Untuk mengatasi hal tersebut, peneliti memilih dan menggunakan permainan bowling botol.. Metode yang digunakan dalam penelitian ini adalah Penelitian Tindakan Kelas Kolaboratif dengan desain penelitian Kemmis dan Taggart. Subjek penelitian ini adalah anak kelompok A, guru RA Al Istiqomah Kecamatan Cihideung Kota Tasikmalaya dan observer. Teknik pengumpulan data yang digunakan adalah observasi dan dokumentasi. Analisis data kuantitatif menggunakan persentase dan data kualitatif menggunakan catatan lapangan. Berdasarkan data yang diperoleh dan hasil analisis, disimpulkan bahwa kemampuan guru dalam perencanaan pembelajaran dan kemampuan guru dalam mengelola proses pembelajaran hasilnya baik, ada perkembangan dari setiap tindakan siklus I sampai siklus III. Kemampuan gerak manpulatif anak melalui permainan bowling botol dari setiap siklus I sampai siklus III hasilnya baik
\end{abstract}

Keyword:

ManipulativeMotion Abstrack

Capability, Bottle

Bowling Game.

\begin{abstract}
This research is motivated by the importance of manipulative ability of early childhood, with the problems that arise that are not optimal manipulative ability in children in group $A$ in $R A A l$ Istiqomah Tasikmalaya City. In gross motor learning, especially in manipulative movements in PAUD, the game used is catching and throwing the ball repeatedly. This is indicated by an indicator of the manipulative ability of the child in throwing and catching the ball is still low.The method used in this research is Collaborative Class Action Research with Kemmis and Taggart research design. The subjects of this study were children of group A, teacher of RA Al Istiqomah, District of Cihideung, Tasikmalaya City and observers. Data collection techniques used are observation and documentation. Quantitative data analysis uses percentages and qualitative data using field notes. Based on the data obtained and the results of the analysis, it was concluded that the teacher's ability in learning planning and the teacher's ability to manage the learning process was good, there was a development of each cycle
\end{abstract}


I to cycle III. Manpulative motility capability of children through bowling game bottle from every cycle I until cycle III result is good.

(C) 2019 Universitas Suryakancana

$$
\begin{aligned}
& \text { Alamat korespondensi: } \\
& \text { E-mail: } \\
& \text { Adirahadian@unsur.ac.id }
\end{aligned}
$$

e-ISSN $: 2721-7175$ (online)

p-ISSN : 2089-2341 (cetak)

\section{PENDAHULUAN}

Berdasarkan Undang-undang

Nomor 20 Tahun 2003 Tentang Sistem

Pendidikan Nasional yang berkaitan dengan Pendidikan Anak Usia Dini tertulis pada Pasal 28 ayat 1 yang berbunyi "Pendidikan Anak Usia Dini adalah suatu upaya pembinaan yang ditujukan kepada anak sejak lahir sampai dengan enam tahun dan bukan prasyarat untuk mengikuti pendidikan dasar". Kemudian pada Peraturan Menteri Pendidikan dan Kebudayaan Republik Indonesia No 146 Tahun 2014 tentang Kurikulum 2013 Pendidikan Anak Usia Dini ditegaskan bahwa,

"Pendidikan anak usia dini adalah suatu upaya pembinaan yang dituujukan kepada anak sejak lahir sampai dengan usia enam tahun yang dilakukan melalui pemberian rangsangan pendidikan untuk membantu pertumbuhan dan perkembangan jasmani dan rohani agar anak memiliki kesiapan dalam memasuki pendidikan lebih lanjut." Anak usia dini sedang berada pada pertumbuhan dan perkembangan fisik yang pesat. Dalam membahas perkembangan anak, digunakan istilah aspek perkembangan anak yaitu aspekaspek yang meliputi perkembangan fisik motorik, kognitif, sosio emosional, bahasa, moral dan agama. Salah satu aspek yang harus dikembangkan yaitu fisik motorik meliputi perkembangan badan, otot kasar, dan otot halus yang disebut motorik kasar dan motorik halus. Sujiono (2005, hlm. 13) berpendapat bahwa gerakan motorik kasar adalah kemampuan yang membutuhkan koordinasi sebagian besar bagian tubuh anak. Gerakan motorik kasar melibatkan aktivitas otot-otot besar seperti otot tangan, otot kaki, dan seluruh tubuh anak. Keterampilan gerak anak dapat dikembangkan dengan baik apabila aspekaspek yang merupakan gerak dasar anak dikembangkan sejak awal yaitu gerak lokomotor, gerak nonlokomotor, dan gerak manipulatif.

Salah satu cara untuk meningkatkan gerak manipulatif anak usia dini adalah dengan permainan. Hurlock (1978, hlm. 280) mengemukakan bahwa permainan adalah proses aktivitas fisik atau psikis yang menyenangkan dan menggembirakan. Oleh karena itu guru harus memahami bahwa banyak kegiatan yang dikembangkan untuk pembentukan otot. permainan yang dapat menarik 
perhatian anak dan meningkatkan perkembangan gerak manipulatif anak usia dini yaitu bowling botol. Bowling botol adalah permainan yang dimainkan dengan cara menggelindingkan bola pada botol menggunakan tangan. Dengan permainan bowling botol akan mengetahui kemampuan gerak manipulatif anak dan tumbuh kembang anak menjadi optimal. Hal ini sejalan dengan penelitian yang dilakukan oleh Hikmah (2017) menyimpulkan bahwa permainan bowling dapat meningkatkan motorik kasar anak. Penelitian sebelumnya lebih berorientasi pada perkembangan motorik kasar anak. Sedangkan dalam penelitian ini yang akan diangkat adalah motorik kasar mengenai peningkatan gerak manipulatif anak melalui permainan bowling botol.

\section{KAJIAN PUSTAKA}

\section{Perkembangan Motorik Kasar Anak}

\section{Usia Dini}

Perkembangan motorik anak terbagi menjadi dua bagian, yaitu gerak motorik kasar dan gerak motorik halus. Kemampuan motorik kasar seseorang berbeda-beda tergantung dengan banyaknya pengalaman gerak yang mereka lakukan. Perkembangan motorik merupakan salah satu aspek pertumbuhan anak-anak yang begitu jelas terlihat. Sanders (dalam Beaty, 2013, hlm. 200) mengemukakan bahwa "kami memahami bahwa perkembangan fisik seorang anak bergantung pada biologinya tetapi kita juga perlu mempertimbangkan pendapat
Vygotsky bahwa kondisi lingkungan sama pentingnya". Menurut Nur, L dkk (2017, hlm. 54) Perkembangan motorik kasar berupa koordinasi gerakan tubuh seperti berlari, berjinjit, melompat, bergantung, melempar, menangkap dan sebagainya. Kegiatan tersebut diperlukan untuk meningkatkan kemampuan koordinasi gerakan motorik kasar.

Menurut Hadis (dalam Yasbiati dkk. 2017, hlm. 47) untuk merangsang motorik kasar anak dapat dilakukan dengan melatih anak untuk meloncat, memanjat, memeras, bersiul, membuat ekspresi muka senang, sedih, gembira, berlari, berjinjit, berdiri diatas satu kaki, berjalan dititian dan sebagainya. Jadi dapat disimpulkan bahwa gerak motorik kasar adalah kemampuan yang membutuhkan koordinasi sebagian besar tubuh anak dan biasanya memerlukan tenaga karena dilakukan oleh otot-otot besar. Pengembangan gerak motorik kasar juga memerlukan koordinasi kelompok otot-otot tertentu yang dapat membuat mereka dapat meloncat, memanjat, berlari, berjalan, berjinjit, berdiri diatas satu kaki, dan lain-lain

\section{Perkembangan Gerak Manipulatif}

Perkembangan gerak manipulatif adalah suatu keterampilan memanipulasi obyek sambil bergerak (Kastrena, dkk, 2020). Kemampuan melempar dan menangkap menjadi salah satu kemampuan manipulatif yang sangat diperlukan. Sumantri (2005, hlm. 99) mengemukakan bahwa "kemampuan menggunakan otot-otot besar ini bagi anak 
usia dini tergolong pada kemampuan gerak dasar, kemampuan ini dilakukan untuk meningkatkan kualitas hidupnya". Selanjutnya kemampuan gerak dasar dibagi menjadi tiga kategori yaitu lokomotor, nonlokomotor, dan manipulatif. Dian (2016, hlm. 77) mengemukakan gerak manipulatif adalah "gerakan yang memakai alat bantu seperti bola. Contoh gerakan ini adalah melempar, menangkap, dan menyepak".

Samsudin (2016, hlm. 18) mengemukakan:

Bentuk-bentuk kemampuan gerak manipulatif terdiri dari gerak mendorong (melempar, memukul, menendang) gerakan menerima (menangkap) objek adalah kemampuan yang penting yang dapat diajarkan dengan menggunakan bola plastik yang terbuat dari bantalan karet (bola medium) atau bola plastik dengan gerakan memantul-mantulkan bola atau menggiring bola.

\section{Aktivitas Permainan Bowling}

Menurut Hurlock (1979, hlm. 280) mengemukakan bahwa permainan adalah proses aktivitas fisik atau psikis yang menyenangkan atau menggembirakan. Sedangkan menurut Dwi, dkk (2016, hlm. 4) bermain adalah suatu kegitan yang dilakukan berulang-ulang dan menimbulkan kesenangan atau kepuasan bagi diri seseorang dan kegiatan yang anak-anak lakukan sepanjang hari, yang nantinya melalui bermain anak akan memperoleh pengetahuan yang dapat mengembangkan kemampuan dirinya.

Suyanto (2005, hlm. 119) mengemukakan bahwa bermain memiliki peranan penting dalam perkembangan pada anak hampir semua bidang perkembangan, baik perkembangan fisik, motorik, bahasa, intelektual, moral, sosial, maupun emosional. Menurut Desmianti (dalam Aryani, dkk, 2015) manfaat permainan bowling adalah "permainan bowling ini lebih berguna untuk melatih ketepatan gerak, koordinasi mata-tangan, dan motorik kasar melalui kegiatan melempar terutama saat anak berupaya menggelindingkan bola ke sasaran yaitu pin bowling. dengan bermain bowling anak juga dapat melatih konsentrasi dan kesabaran.

Asamasubrata (2012, hlm. 106) mengartikan permainan bowling juga sebagai suatu jenis olahraga atau permainan menggelindingkan atau melempar bola dengan menggunakan tangan. Bola bowling dilemparkan ke pin (gada) yang berderet dan berjumlah 10 buah yang telah di susun menjadi bentuk segitiga jika dilihat dari atas. Desmianti (dalam Aryani, dkk, 2015) menyatakan bahwa permainan bowling merupakan permainan yang menggunakan gerakan mata dan tangan secara bersamaan, permainan yang menggunakan alat sebagai media melakukan kegiatan.

Langkah-langkah dalam permainan bowling menurut Strickland (dalam Aryani dkk, 2015) yaitu: 
1) Bola bowling akan digelindingkan atau dilempar ke pin yang berjumlah sepuluh buah yang telah disusun menjadi bentuk segitiga jika dilihat dari atas.

2) Jika semua pin dijatuhkan dalam sekali gelinding (lemparan) maka itu disebut strike

3) Jikapun tidak dijatuhkan sekaligus maka diberikan satu kali kesempatan lagi untuk menjatuhkan pin yang tersisa

4) Bilamana pada lemparan kedua tidak ada lagi pin tersisa disebut spare

5) Jika setelah dua kali masih ada pin yang tersisa maka disebut open prame (missed) yang kesemuanya itu akan menentukan perhitungan angka yang didapat dalam setiap game nya

6) Pin akan kembali disusun seperti semula untuk prame selanjutnya

Permainan bowling di Taman Kanakkanak dapat dilakukan dengan memodifikasi permainan bowling baik itu alat ataupun aturan permainannya sesuai dengan tingkat kemampuan anak usia kelompok A menjadi lebih sederhana dan dapat dipahami oleh anak. Bola bowling yang digunakan dalam permainan umumnya memiliki ukuran yang berat dan tidak mungkin digunakan oleh anak usia dini, sehingga yang digunakan dalam penelitian ini adalah botol bekas dan bola karet. Untuk alasnya menggunakan banner berukuran 5x1M2 agar dapat dimainkan dimana saja (indoor maupun outdoor). Banner tersebut diberi garis pinggir dan garis tengah sebagai jarak atau tanda untuk anak.

Dalam melakukan aktivitas bermain, selalu ada langkah-langkah dalam pelaksanaanya. Langkah-langkah dalam melaksanakan aktivitas bermain bowling botol adalah sebagai berikut:

1) Guru mengajak anak untuk berbaris, agar lebih kondusif dilakukan dengan bernyanyi. Kemudian guru menjelaskan aturan main sambil memperagakan cara bermainnya. Keaktifan anak dalam bermain menandakan anak memahami akan aturan yakni, anak harus fokus menangkap dan melempar bola pada botol untuk menjatuhkan botol tersebut.

2) Kemudian anak berdiri dengan jarak 5 meter dari sasaran (pin)

3) Teman-temannya yang lain berbaris menunggu giliran

4) Anak yang berada di barisan pertama melempar bola pada pemain

5) Posisi awal anak sebelum melempar adalah sikap berdiri tegak dan memegang bola dengan menggunakan tangan

6) Anak berdiri lurus mengarah ke pin yang akan dilempar dan posisi kaki berada tepat di batas garis permainan untuk bersiap-siap melemparkan bola 
7) Anak memegang bola, kemudian posisi badan anak sedikit membungkuk

8) Anak kemudian melemparkan bola kearah botol yang ada didepan anak

9) Setiap anak diberikan tiga kali kesempatan melempar, jika lemparan belum mengenai sasaran, anak dapat mencoba kembai untuk melempar.

\section{METODE PENELITIAN}

\section{Jenis Penelitian}

Metode penelitian yang digunakan adalah Penelitian Tindakan Kelas (PTK). Sugiyono (2012, hlm. 3) mengemukakan bahwa metode penelitian secara umum dapat diartikan sebagai cara ilmiah untuk mendapatkan data dengan tujuan dan kegunaan tertentu. Maka dapat disimpulkan bahwa metode penelitian adalah suatu cara yang digunakan untuk mendapatkan data yang dilakukan secara ilmiah berdasarkan tujuan yang akan dicapai.

Penelitian tindakan kelas ini dilaksanakan sebagai salah satu upaya untuk meningkatkan kualitas proses dan hasil penbelajaran. Penelitian tindakan kelas juga berguna bagi guru dalam meningkatkan kreativitas guru dalam melakukan proses kegiatan pembelajaran dan meningkatkan kompetensi dan keprofesionalan seorang guru dalam melakukan pembelajaran.

Model Penelitian Tindakan Kelas (PTK) yang digunakan dalam penelitian ini adalah model dikembangkan oleh Kemmis dan Robbin Mc. Taggart Model penelitian tindakan kelas diatas terdiri dari beberapa siklus. Setiap siklus terdiri dari perencanaan, tindakan, observasi, dan refleksi.

Model siklus yang dikembangkan oleh Kemmis dan Mc. Taggart juga sering disebut siklus spiral, dimana jika pada siklus pertama rencana pembelajaran, pelaksanaan pembelajaran dan hasil belajar kurang baik maka akan dilakukan pada seklus kedua, dengan melakukan perbaikan-perbaikan sesuai dengan hasil atau refleksi dari siklus pertama. Begitu pula jikan siklus kedua masih ditemukan kekurangan pada rencana pembelajaran, pelaksanaan pembelajaran dan hasil belajar maka akan dilanjutkan pada siklus ketiga, sampai penelitian yang dilakukan sesuai dengan tujuan yang diharapkan oleh peneliti. Batas penelitian jika sudah sampai pada tahap saturasi atau sudah habis gagasan dan juga keterbatasan waktu dari peneliti.

\section{Subjek Penelitian}

Subjek penelitian adalah anak kelas A RA Al-Istiqomah tahun ajaran 2017/2018 pada kelas A dengan jumlah anak 16 orang. Pada penelitian tindakan kelas dibantu oleh guru kelas A yaitu Ibu Rina Siti Hoeriah S.Pd.I. dan Ibu Eva Farlina, S.Pd.I. Objek penelitian ini adalah peningkatan kemampuan gerak manipulatif anak melalui permainan bowling botol.

3. Variabel dan Definisi Operasional Variabel 
Sugiyono (2012, hlm. 60) mengemukakan variabel penelitian adalah "segala sesuatu yang berbentuk apa saja yang ditetapkan oleh peneliti untuk dipelajari sehingga diperoleh informasi tentang hal tersebut, kemudian ditarik kesimpulan nya". Dalam penelitian ini terdapat dua variabel yakni:
1) Variabel proses : Permainan bowling botol
2) Variabel hasil : Peningkatan
kemampuan gerak manipulatif

\section{Instrumen penelitian}

Sugiyono (2012, hlm.148) mengemukakan Instrumen penelitian adalah suatu alat ukur yang digunakan mengukur fenomena alam maupun sosial yang diamati. Pada tahap ini penulis menggunakan lembar observasi yang merupakan daftar serangkaian kegiatan yang ada dalam penelitian dan sebagai objek yang akan diamati oleh peneliti. Jadi dalam penelitian ini peneliti menggunakan lembar observasi untuk mengetahui kemampuan gerak manipulatif anak melalui permainan bowling botol.

\section{Pengumpulan Data}

\section{a. Data}

Pada penelitian ini menggunakan data primer dan data sekunder. Dimyanti (2013, hal. 39) menjelaskan "Data primer diperoleh dari sumber data pertama, dari subjek atau objek penelitianlah data penelitian langsung diambil". Sumber data primer pada penelitian ini yaitu uru dan anak kelompok A RA Al Istiqomah Kota Tasikmalaya. Pada data sekunder diambil dari data sebelumnya. Dimyanti (2013, hal. 39) menjelaskan bahwa "Data sekunder diambil dari pihak mana saja yang bisa memberikan tambahan data guna melengkapi kekurangan dari data yang diperoleh melalui sumber data". Dta sekunder diambil dari dokumentasi di RA Al Istiqomah Kota Tasikmalaya.

\section{b. Sumber Data}

Sumber data penelitian ini berasal dari kepustakaan yaitu dari buku, artikel, dan jurnal yang berkaitan dengan peennelitian ini. Dan lapangan dimana dalam sebuah penelitian tida lepas dari kata lapangan, lapangan disini untuk mengumpulkan informasi menjadi sebuah data dan kemudian akan itemukan hasilnya.

\section{c. Rencana}

Pelaksanaann

\section{Pembelajaran Harian (RPPH)}

Rencana Pelaksanaan Pembelajaran Harian (RPPH) adalah sumber data yang diambil data-datanya untuk kepentingan penelitian. RPPH yang digunakan tentang berbagai tema, hanya saja dikegiatan awal ada motorik kasar yaitu permainan bowling botol.

\section{Teknik Pengumpulan Data}

Teknik pengumpulan data merupakan langkah-langkah yang digunakan untuk mengumpulkan data. Teknik pengumpulan data yang digunakan pada penelitian Peningkatan kemampuan gerak manipulatif melalui permainan bowling botol di kelas A RA Al Istiqomah Kota Tasikmalaya adalah observasi dan dokumentasi yang berguna untuk 
mengetahui sejauh mana perkembangan anak, berikut penjelasannya:

\section{a. Observasi}

Hadi (dalam Sugiyono, 2012 hlm. 203) mengemukakan bahwa "observasi merupakan suatu proses yang kompleks, suatu proses yang tersusun dari berbagai proses biologis dan psikologis. Dua diantaranya adalah proses-proses pengamatan dan ingatan". Observasi yang dilakukan pada penelitian ini adalah observasi partisipatif yaitu saya terlibat langsung dalam proses kegiatan pembelajaran. Dalam penelitian ini, peneliti mengobservasi secara langsung anak dan guru. Pada anak, peneliti mengobservasi kemampuan gerak manipulatif. Pada guru peneliti, mengobservasi kemampuan guru dalam perencanaan dan pelaksanaan pembelajaran.

\section{b. Dokumentasi}

Menurut Dimyanti (2013, hlm. 100) "metode dokumentasi yaitu teknik pengumpulan data penelitian mengenai hal-hal atau variabel yang berupa transkip, buku, surat, koran, majalah, prasasti, notulen rapat, leger nilai, dan lain-lain".

Dalam penelitian ini mengambil gambar secara nyata pada saat kegiatan pembelajaran anak dalam peningkatan kemampuan gerak manipulatif melalui dan kemampuan guru dalam perencanan dan pelaksanaan melalui permainan bowling botol serta memperkuat data yang telah diperoleh.

\section{Teknik Analisis Data}

Sukardi (2015, hlm. 72) "analisis adalah proses memecahkan satu atau beberapa permasalahan melalui data yang ada, dan kemudian memasukannya kedalam komponen penelitian".

"Menrut Sugiono (2012, hlm. 355) menyatakan bahwa analisis data adalah proses mencari menyusun secara sistematis data yang diperoleh dari hasil wawancara, catatan lapangan, dan dokumentasi, dengan cara menganalisiskan data kedalam kategori, menjabarkan kedalam unit-unit, melakukan sintesa, menyusun ke dalam pola, memilih mana yang penting dan yang akan dipelajari, dan membuat kesimpulan sehingga mudah dipahami diri sendiri maupun orang lain".

Menurut Wardhani (2007, hal. 59) "Teknik analisis data adalah merangkum data dengan cara yang akurat dan dapat dipertanggungjawabkan sehingga mampu memberikn makna". Analisis dalam penelitian ni akan menggunakan deskriptif kuantitatif yaitu data yang dikumpulkan pada setiap pelaksanaan siklus dianalisis menggunakan teknik presentase.

Menurut Purwanto (2006, hlm. 102) persentase dapat dicari menggunakan rummus beikut:

$P=\frac{F}{N} \times 100$

\section{Keterangan:}

$\mathrm{P}=$ angka persentase

$\mathrm{F}=$ skor mentah yang diperoleh siswa 
$\mathrm{N}=$ skor maksimum

Adapun kriterianya yaitu sebagai berikut:

1. Kriteria sangat baik jika anak memperoleh nilai $76 \%-100 \%$

2. Krritriaa baik jika anak memperoleh nilai $51 \%-75 \%$

3. Kriterian cukup jika anak memperoleh nilai $26 \%-50 \%$

4. Kriteria kurang jika anak memperoleh nilai $0 \%-25 \%$

Dari persntase di atas, penelitian ini mengambil empat presentase yang di adaptasi dari pendapat Yoni (2010, hlm. 176) dan prosedur penelitian di TK atau RA yaitu:

Tabel 1.

Kriteria Kemampuan Gerak Manipulatif

\begin{tabular}{c|l|c}
\hline No & \multicolumn{1}{|c}{ Kriteria } & Persentase \\
\hline & BSB & $76 \%-$ \\
1 & $\begin{array}{l}\text { (Berkembang } \\
\text { Sangat Baik) }\end{array}$ & $100 \%$ \\
\hline & $\begin{array}{l}\text { BSH } \\
\text { (Berkembang } \\
2\end{array}$ & $\begin{array}{l}\text { Sesuai } \\
\text { Harapan) }\end{array}$ \\
\hline 3 & $\begin{array}{l}\text { MB (Mulai } \\
\text { Berkembang) }\end{array}$ & $26 \%-50 \%$ \\
\hline 4 & $\begin{array}{l}\text { BB (Belum } \\
\text { Berkembang) }\end{array}$ & $0 \%-25 \%$ \\
\hline
\end{tabular}

Keberhasilan penelitian tindakan

kelas ditandai dengan adanya perubahan menuju arah yang perbaikan. Berikut merupakan indikator keberhasilan pada penelitian ini :

1) Guru mengalami peningkatan kemampuan dalam proses perencanaan pembelajaran dan pelaksanaan

pembelajaran khususnya pada peningkatan kemampuan gerak manipulatif melalui permainan bowling botol.

2) Guru mengalami peningkatan kemampuan dalam mengelola proses pembelajaran dengan melalui permainan bowling botol untuk meningkatkan kemampuan gerak manipulatif anak.

3) Anak mengalami peningkatan kemampuan gerak manipulatif melalui permainan bowling botol yang telah mencapai indikator keberhasilan yang telah ditentukan yaitu minimal anak berada pada kriteria Berkembang Sesuai Harapan (BSH).

\section{HASIL DAN PEMBAHASAN}

Penelitian penggunaan permainan bowling botol untuk meningkatkan kemampuan gerak manipulatif anak telah dilaksanakan melalui tiga siklus. Sebelum dilaksanakan terlebih dahulu pra tindakan yaitu pada tanggal 26 April 2018, siklus I dilaksanakan pada tanggal 07 Mei 2018 dengana tema Negaraku dan sub tema wisata laut pada siklus I merupakan tahap perencanaan dari permainan bowling botol. Siklus II dilaksanakan pada tanggal 08 Mei 2018, dengan tema Negaraku dan sub tema pegunungan. Siklus III dilaksanakan pada tanggal 09 Mei 2018 dengan tema Negaraku dan sub tema museum. 
1) Pereencanaan Kegiatan dalam Mengembangkan Kemampuan Gerak Manipulatif

Perencanaan pembelajaran pada Penelitian Tindakan Kelas ini dituangkan dalam tiga Rencana Pelaksanaan Pembelajaran Harian (RPPH) berikut merupakan tabel rekapitulasi kemampuan guru dalam membuat Rencana Pelaksanaan Pembelajaran Harian.

kemampuan guru dalam membuat RPPH mengalami peningkatan hal ini dapat terjadi karena adanya perbaikanperbaikan yang dilakukan oleh guru. Data hasil observasi penilaian Rencana Pelaksanaan Pembelajaran Harian (RPPH) pada siklu I diperoleh kekurangan yaitu dalam pengembangan rancangan dalam permainan bowling botol masih kurang optimat, pemilihan metode pembelajaran pada kegiatan permainan bowling botol masih belum optimal, pemanfaatan media dalam kegiatan permainan bowling botol masih belum optimal, pemanfaatan media dalam permainan bowling botol masih belum optimal, dan persiapan guru terutama dalam kelengkapan dari lampiran-lampiran masih kurang. Pada siklus I kemampuan guru dalam membuat Rencana Pelaksanaan Pembelajaran Harian (RPPH) yaitu $64,58 \%$ dalam kriteria cukup. Kekurangan pada siklus I diperbaiki dalam perencanaan pada siklus II. Pada siklus II kekurangan dari siklus I sudah diperbaiki namun dalam kesesuaian tema dengan kegiatan masih belum diperbaiki secara optimal dikarenakan beberapa kendala, pada siklus II kemampuan guru dalam membuat membuat Rencana Pelaksanaan Pembelajaran Harian (RPPH) yaitu 70,83\% masih dalam kriteria Cukup. Kekurangan pada siklus II diperbaiki di siklus III sehingga peningkatan kemampuan guru dalam membuat Rencana Pelaksanaan Pembelajaran Harian (RPPH) yaitu 79,16\% sudah pada kriteria baik.

peningkatan kemampuan guru dalam membuat Rencana Pelaksanaan Pembelajaran dari siklus I, siklus II, dan siklus III dapat dilihat pada gambar berikut ini :

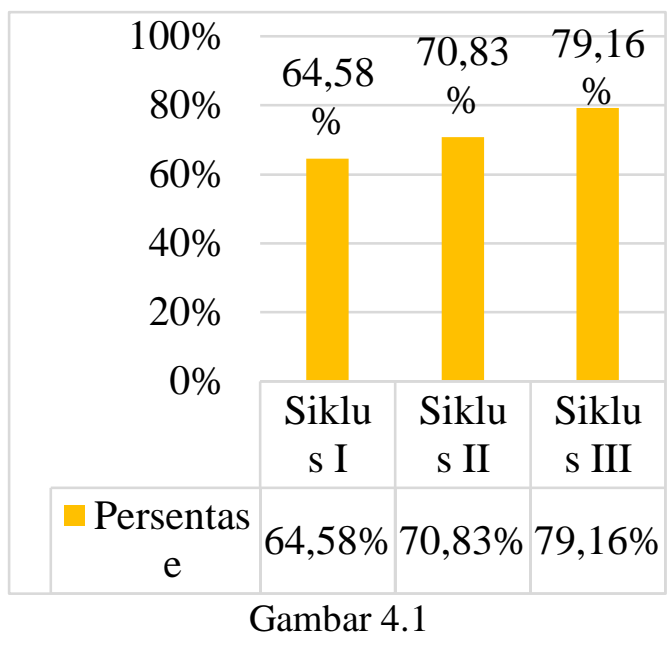

Hasil Rekapitulasi Kemampuan Guru dalam Perencanaan Pembelajaran

Siklu I, Siklus II, Siklus III

Secara umum hasil observasi kemampuan guru dalam kegiatan permainan bowling botol mengalami peningkatan dari setiap siklusnya, yaitu siklus I, siklus II, dan siklus III.

pada siklus I merupakan tahap persiapan kegiatan permainan bowling 
botol mengalami kekurangan yaitu dalam mengkondisikan anak masih kurang menguasai sehingga anak tidak kondusif. Jadi kemampuan guru dalam pembelajaran melalui permainan bowling botol pada siklus I yaitu mencapai 60 berada dalam kriteria cukup.

Kekurangan pada siklus I tersebut sudah diperbaiki pada siklus II, yaitu guru sudah mampu mengkondisikan anak. Pada siklus II merupakan tahap pelaksanaan dari permainan bowling botol yang sebelumnya sudah direncanakan pada siklus I, diperoleh kekurangan pada siklus II yaitu guru kurang memotivasi dan membimbing anak saat pelaksanaan permainan bowling botol sehingga anak kurang terlibat aktif, jadi kemampuan guru pada siklus II mencapai skor 65 berada pada kriteria cukup.

Pada siklus III merupakan tahap penilaian dari kegiatan pembelajaran melalui permainan bowling botol, kekurangan pada siklus II sudah diperbaiki pada siklus III, jadi kemampuan guru dalam kegiatan pembelajaran melalui permainan bowling botol mencapai skor 75 berada pada kriteria baik.

Kegiatan pembelajaran melalui permainan bowling botol dapat meningkatkan kemampuan gerak manipulatif anak. "permainan bowling botol ini anak dapat melakukan gerakangerakan seperti menangkap dan melempar. Sehingga dapat meningkatkan koordinasi mata dan tangan. Bowling botol adalah sebuah latihan yang dilakukan dengan cara melempar bola pada botol (hingga botol terjatuh) permainan bowling botol ini dilakukan secara bergantian dan tidak dibatasi jumlah pemainnya. Rahayudi (2012, hlm. 305) "gerak manipulatif adalah gerakan yang memerlukan koordinasi dengan ruang dan benda yang ada disekitarnya. Gerak manipulatif melibatkan tindakan mengontrol suatu objek khususnya dengan tangan dan kaki."

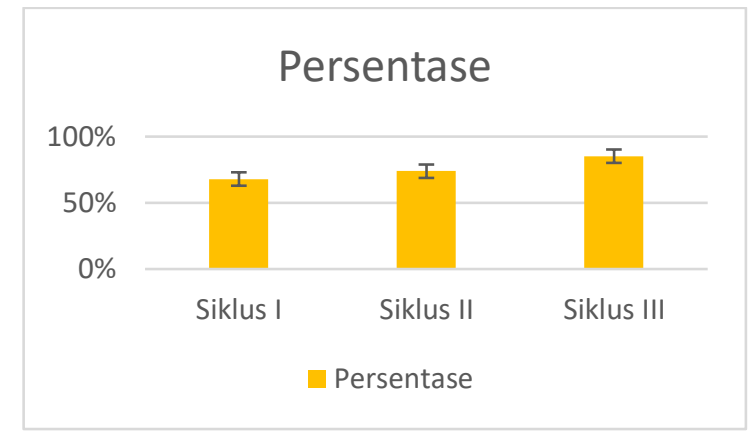

Gambar 4.2

\section{Hasil Rekapitulasi Kemampuan Guru}

dalam Pelaksanaan Pembelajaran

Melalui Permainan Bowling Botol Siklus

\section{I, Siklus II, Siklus III}

Kemampuan gerak manipulatif sangat penting untuk anak, tanpa kemampuan gerak manipulatif yang memadai, aktivitas anak seringkali terhambat dan hasilnya tidak optimal. Kemampuan gerak manipulatif lebih banyak melibatkan tangan dan kaki, tetapi bagian tubuh lain juga dapat digunakan serta gerak manipulatif terlibat dalam kehidupan sehari-hari. Contoh gerakan manipulatif adalah melempar, menangkap, menendang, menggiring, dan memukul.

Kemampuan gerak manipulatif perlu dikembangkan sejak dini, berikut 
merupakan perkembangan kemampuan gerak manipulatif anak 4-5 tahun dalam Standar Tingkat Pencapaian Perkembangan Anak dalam Permendikbud No 137 tahun 2014, yaitu:

1) Melempar sesuatu secara terarah

2) Menangkap sesuatu secara tepat

3) Menendang sesuatu secara terarah

Peningkatan kemampuan gerak manipulatif anak dilakukan sebanyak III siklus, siklus I dilaksanakan pada tanggal 07 Mei 2018, siklus II dilaksanakan pada tanggal 08 Mei 2018, dan siklus III dilaksanakan pada tanggal 09 Mei 2018. Penelitian ini menggunakan empat kriteria penilaian yaitu Belum Berkembang (BB) dengan persentase $0 \%-25 \%$, Mulai Berkembang (MB) dengan persentase 26$50 \%$, Berkembang Sesuai Harapan (BSH) dengan persentase 51\%-75\%, Berkembang Sangat Baik (BSB) dengan persentase 76\%-100\%. Untuk memperjelas rekapitulasi peningkatan kemampuan gerak manipulatif anak dari mulai siklus I, siklus II, dan siklus III dapat dilihat pada gambar 4.3 berikut:

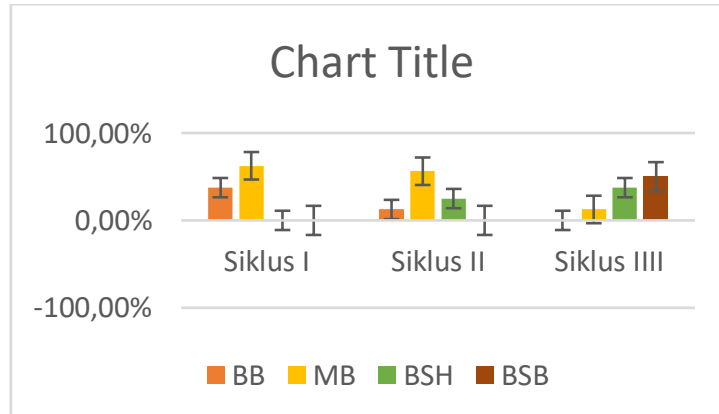

Gambar 3. Hasil Rekapitulasi

Kemampuan Gerak Manipulatif Anak
Melalui Permainan Bowling Botol Siklus

I, Siklus II, Siklus III

kemampuan gerak manipulatif indikator melakukan gerakan menangkap bola secara tepat dan melempar bola secara terarah siklus I pada kriteria Belum Berkembang (BB) enam anak dengan persentase $37,5 \%, \quad 10$ anak dengan persentase $62,5 \%$ beada pada kriteria Mulai Berkembang (MB). Pada siklus II kriteria Belum Berkembang (BB) 2 orang anak dengan persentase $12,5 \%, 10$ orang anak berada pada kriteria Mulai Berkembang (MB) dengan persentase $56,25 \%$, dan 4 orang anak berada pada kriteria Berkembang Sesuai Harapan (BSH) dengan persentase 25\%. Dan pada siklus III pada kriteria Mulai Berkembang (MB) dua orang dengan persentase $12,5 \%$, pada kriteria Berkembang Sesuai Harapan (BSH) enam orang dengan persentase $37,5 \%$, dan pada kriteria Berkembang Sangat Baik (BSB) delapan orang dengan persentase $50 \%$.

Data pada gambar 4.3 menunjukan bahwa kemampuan gerak manipulatif anak mengalami peningkatan setelah menggunakan kegiatan pembelajaran melalui permainan bowling botol. Kegiatan pembelajaran melalui permainan bowling botol dapat meningkatkan kemampuan gerak manipulatif anak. Permainan bowling botol ini anak dapat melakukan gerakan menangkap secara tepat dan melempar secara terarah. Permainan bowling botol ini dilakukan secara bergantian dan tidak terbatas jumlah 
pemain. Menurut Heri Rahayudi (2012, hlm. 305) gerak manipulatif adalah gerakan yang memerlukan koordinasi dengan ruang dan benda yang ada disekitarnya. Gerak manipulatif melibatkan tindakan mengontrol suatu objek khususnya dengan tangan dan kaki.

Secara umum keseluruhan aspek kinerja guru dan perkembangan kemampuan gerak manipulatif anak dari mulai siklus I, siklus II, dan siklus III dapat dikatakan berhasil walaupun tingkat ketercapaiannya belum sempurna. Pada pembelajaran siklus III peningkatan kemampuan gerak manipulatif melalui permainan bowling botol yang terdiri dari persiapan dengan membuat Rencana Pelaksanaan Pembelajaran Harian (RPPH), pelaksanaan kegiatan pembelajaran melalui permainan bowling botol telah meningkat secara optimal, oleh karena itu penelitian dihentikan hingga siklus III karena kemampuan gerak manipulatif anak sudah meningkat sesuai dengan indikator keberhasilan yang telah ditentukan. Dengan demikian dapat disimpulkan bahwa permainan bowling botol dapat meningkatkan kemampuan gerak manipulatif anak pada kelompok A RA Al Istiqomah Kota Tasikmalaya

\section{KESIMPULAN}

\section{Simpulan}

\section{Berdasarkan hasil Penelitian}

Tindakan Kelas yang telah dilaksanakan melalui beberapa tindakan dari siklus I, siklus II, siklus III mengenai penerapan permainan bowling botol untuk meningkatkan kemampuan gerak manipulatif anak pada kelompok A RA Al Istiqomah Kota Tasikmalaya, dapat diperoleh kesimpulan sebagai berikut:

1) Perencanaan pembelajaran melalui permainan bowling botol untuk meningkatkan kemampuan gerak manipulatif anak pada kelompok A RA Al Istiqomah Kota Tasikmalaya yang disusun oleh peneliti sudah sesuai dengan kriteria keberhasilan. Rencana Pelaksanaan Pembelajaran Harian (RPPH) yang digunakan sebagai pedoman pelaksanaan pembelajaran. Selain itu peneliti mempersiapkan lembar observasi kemampuan guru dalam merencanakan pembelajaran maupun kemampuan guru dalam melaksanakan pembelajaran melalui permainan bowling botol serta lembar observasi anak. Kemampuan guru dalam merencanakan pembelajaran melalui permainan bowling botol untuk meningkatkan kemampuan gerak manipulatif anak mengalami peningkatan pada setiap siklus. Dalam siklus I kemampuan guru dalam merencanakan pelaksanaan pembelajaran ini termasuk kedalam kategori cukup dan perlu ditingkatkan kembali, siklus II termasuk kedalam kategori cukup dan perlu ditingkatkan kembali, dan siklus III sudah termasuk kedalam kategori baik. Hal ini terjadi karena adanya refleksi serta perbaikanperbaikan yang telah dilaksanakan. 
2) Pelaksanaan pembelajaran dengan melalui permainan bowling botol untuk meningkatkan kemampuan gerak manipulatif anak di kelompok A RA Al Istiqomah Kota Tasikmalaya ternyata dapat meningkatkan kemampuan guru dalam kegiatan pembelajaran melalui permainan bowling botol. Hali ini dibuktikan dengan adanya peningkatan kemampuan guru dalam melaksanakan pembelajaran pada setiap siklus. Pada siklus I kemampuan guru dalam merencanakan pelaksanaan pembelajaran ini termasuk ke dalam kategori cukup dan perlu ditingkatkan kembali, siklus II termasuk kedalam kategori cukup dan perlu ditingkatkan kembali, dan siklus III sudah termasuk kedalam kategori baik. Peningkatan ini terjadi karena adanya refleksi dan perbaikan-perbaikan yang telah dilakukan.

3) Kemampuan gerak manipulatif anak di kelompok A RA Al Istiqomah Kota Tasikmalaya mengalami peningkatan yang baik pada setiap siklus. Dalam siklus I dengan indikator melakukan menangkap secara tepat dan melempar secara terarah termasuk kedalam kategori Mulai Berkembang (MB). Dari dua indikator terdapat indikator yang paling banyak dilakukan oleh anak yaitu anak mampu melempar bola secara terarah. Sedangkan pada siklus II dengan indikator mampu menangkap bola secara tepat dan melempar bola secara terarah masih dalam kategori
Mulai Berkembang (MB). Dari dua indikator tersebut terdapat satu indikator yang paling banyak di lakukan oleh anak yaitu melempar bola secara terarah. Dan pada siklus III dengan indikator menangkap bola secara tepat dan melempar bola secara terarah termasuk kedalam kategori Berkembang Sangat Baik (BSH). Dari dua indikator terdapat satu indikator yang banyak di lakukan oleh anak yaitu melempar bola secara terarah.

\section{Implikasi}

Penelitian ini dilakukan dalam konteks pendidikan, sehingga kesimpulan yang peneliti simpulkan mempunyai keterlibatan dan implikasi dalam konteks pendidikan dan penelitian selanjutnya. Dengan demikian implikasi dari penelitian ini sebagai berikut:

1) Memberikan impormasi mengenai kegiatan pembelajaran melalui permainan bowling botol dalam pembelajaran dapat mengembangkan kemampuan gerak manipulatif anak.

2) Memotivasi guru untuk menciptakan inovasi dalam kegiatan pembelajaran yang lebih efektif sehingga kemampuan gerak manipulatif anak dapat berkembang optimal.

3) Memberikan gambaran kepada guru dalam merancang pembelajaran melalui kegiatan permainan bowling botol.

\section{Rekomndasi}

Dalam meningkatkan kualitas pembelajaran untuk meningkatkan kemampuan gerak manipulatif anak usia 
dini, peneliti menyampaikan beberapa rekomendasi sebagai berikut:

a. Bagi Guru

Proses pembelajaran yang dilakukan oleh guru dapat dijadikan landasan bahwa kegiatan pembelajaran pada anak usia dini tidak hanya belajar di dalam kelas, tetapi anak dapat belajar dari lingkungan sekitar. Guru dapat memilih kegiatan yang tepat dan tepat untuk digunakan dalam proses pembelajaran di kelas dan sesuai dengan minat dan kebutuhan anak khususnya kegiatan pembelajaran yang dapat meningkatkan kemampuan gerak manipulatif anak usia dini salah satunya permainan bowling botol.

b. Bagi Sekolah

Diharapkan, sekolah merupakan beberapa kegiatan pembelajaran yang sesuai dengan minat dan kebutuhan anak, sehingga kemampuan gerak manipulatif anak dapat berkembang secara optimal.

c. Bagi Peneliti Lainnya

Peneliti mengenai cara meningkatkan kemampuan gerak manipulatif melalui permainan bowling botol pada proses pembelajaran ini masih mempunyai banyak kekurangan yang harus diperbaiki. Peneliti selanjutnya dapat berinovasi dengan menerapkan kegiatan yang lebih baik. Sehingga anak semakin antusuias dalam mengikuti kegiatan pembelajaran.

\section{DAFTAR PUSTAKA}

Arikunto, S. (2008). Prosedur Penelitian Suatu Pendekatan Praktis. Jakarta: Rineka Cipta.
Aryani P, dkk. (2015). Penerapan Metode Pemberian Tugas Berbantuan Media Bowling Untuk Meningkatkan Kemampuan Mengenal Konsep Huruf Pada Anak. Universitas Pendidikan Ganesha. e-Journal PG PAUD, 3 (1), 3 .

Asmasubrata, G. (2012). Serba Tahu Dunia Olahraga. Surabaya: Dafa Publishing

Beaty, J.J. (2013). Observasi Perkembangan Anak Usia Dini. Jakarta: Kencana

Dimyanti, J. (2013). Metodologi Penelitian Pendidikan dan Aplikasinya paa Pendidikan Anak Usia Dini (PAUD). Jakarta: Kencana.

Djamarah, S.B, dan Zein, A. (2010). Strategi Belajar Mengajar. Jakarta: Rineka Cipta

Hurlock, E.B. (1978). Perkembangan Anak. Jakarta: Penerbit Erlangga. Hidayanti, M. (2013). Peningkatan Kemampuan Motorik Kasar Anak Melalui Permainan Bakiak. Universitas Negeri Jakarta. Jurnal Pendidikan Anak Usia Dini, 7 (1), 196.

Hidayat, S. Dan Nurl, L. (2018). Nilai Karakter, Berfikir Kriti Dan Psikomotorik Anak Usia Dini. Universitas Pendidikan Indonesia Kampus Tasikmalaya. Jurnal ilmiah VISI PGTK PAUD dan DIKMAS, 13 (1), 30. Doi: 
https://doi.org./10.21009/JIV.130

1.4

Iskandar, B. (2005). Pengembangan

Motorik Anak Usia Pra Sekolah.

Bandung: Departemen Pendidikan Nasional

Kamus Besar Bahasa Indonesia (KBBI).

Kastrena, E., Suherman, A., Ma'mun, A., Nugraha, E., \&. Nur, L. (2020). Long Jump Ability: A Comparison Between Students with High and Low Physical Fitness. Proceedings of the 4th International Conference on Sport Science, Health, and Physical Education (ICSSHPE 2019). Atlantis Press.

Katmini, dan Tanjung, H.W. (2005). Bermain Melalui Gerak dan Lagu di

Kelas. Jakarta: PT Indeks.

Mirawati, dan Rahmawati, E. (2017).

Permainan Modifikasi Untuk

Stimulasi

Keterampilan Gerak Dasar Manipulatif

Anak Usia 2-4 Tahun. Jurnal Pendidikan: Early Childhood. 2, 78.

Musfiroh, T. dan Tatminingsih, S. (2015).

Bermain Dan Permainan Anak.

Tanggerang Selatan: Universitas Terbuka.

Nur, L. (2016). Pendidikan Jasmani Dan Olahraga. Bandung: Rizqi Press

Nur, L. dkk. (2017). Permainan Tradisional Kaulinan Barudak Untuk Mengembangkan Sikap Empati dan Pola Gerak Dasar An ak Usia Dini. Program Studi PGPAUD UPI Kampus Tasikmalaya. Jurnal PGPAUD Agapedia, 1 (2). 172.

Nur, L. dkk. (2017). Permainan Bola Kecil Untuk Meningkatkan

Keterampilan Motorik Kasar Anak Usia Dini Pada Kelompok B di TK Pertiwi DWP Kota Tasikmalaya. Program Studi PGPAUD UPI Kampus Tasikmalaya. Jurnal PGPAUD Agapedia, 1 (1). 54.

Peraturan Menteri Pendidikan dan Kebudayaan Nomor 137 Tahun 2014

Tentang Standar Nasional Pendidikan Anak Usia Dini.

Purwanto, N. (2006). Prinsip-Prinsip dan Teknik Evaluasi Pengajaran. Bandung: PT Remaja Rosdakarya. Rahyudi, H. (2012). Teori-Teori Belajar Dan Aplikasi Pembelajaran Motorik

Deskripsi dan Tinjauan Kritis. Bandung: Referens

Hikmah, R.D.N. (2017). Penerapan Bermain Bowling Dalam Meningkatkan Motorik Kasar Anak Usia Dini di Raudhatul Athfal Nahdatul Ulama Mataram Baru Lampung Timur. Insitut Agama Islam Negeri Raden Intan Lampung.

Samsudin. (2008). Pembelajaran Pendidikan Jasmani Olahraga dan kesehatan (SD/MI). Jakarta 
Sari P, dkk. (2016). Penerapan Permainan Bola Gelinding (Bowling) Untuk Meningkatkan Kemampuan Mengenal Bilangan Pada Anak Kelompok A. e-Jurnal Pendidikan Anak Usia Dini Universitas Pendidikan Ganesha Jurusan Pendidikan Guru Pendidikan Anak Usia Dini, 4 (2), hlm,4.

Sujiono, B. (2005). Metode Pengembangan Fisik. Jakarta: Universitas

Terbuka.

Sugiyono. (20 11). Metode Penelitian Pendidikan Anak Usia Dini. Jakarta: Kualitatif dan R\&D). Bandung: Alfa Beta.

Sugiyono. (2013). Metode Penelitian

Pendidikan.(Pendekatan

Kuantitatif, Kualitatif dan R\&D).

Bandung. Alfa Beta.

Ma'mun, A. dan Yudha, M.S. (2000).

Perkembangan Gerak dan Belajar.

Direktorat Jenderal Pendidikan

Dasar dan Menengah.

Sujiono, N.Y. (2013). Konsep Dasar Pendidikan Anak Usia Dini. Jakarta:

PT Indeks.

Sulistyani, B. (2016). Jurnal Pendidikan Anak Usia Dini Edisi 9 Tahun ke52016 919. Paud FIP: Universitas Negeri Jakarta.

Sumantri. (2005). Model Pengembangan Keterampilan Motorik Anak Usia

Dini Taman K anak-Kanak. Jakarta: DEPDIKNAS
Sumantri, M.S. dan Endrawati, T. (2010). Kemampuan Sosialisasi Dan Gerak Manipulatif Anak Usia Dini. Jakarta Utara.

Suyanto, S. (2005). Konsep Dasar Pendidikan Anak Usia Dini.

Yogyakarta: Universitas Negeri Yogyakart Tedjasaputra, S.M. (2001). Bermain, Mainan, dan Permainan. Jakarta: Grasindo.

Undang-Undang nomor 20 tahun 2003 tentang Sistem Pendidikan Nasional Bab 1 pasal 1 butir 14.

Vanagosi, D. (2016). Konsep Gerak Dasar Untuk Anak Usia Dini. Jurnal Pendidikan Kesehatan Rekreasi. Fakultas Pendidikan Olahraga dan Kesehatan, IKIP PGRI Bali Program Studi Pendidikan Jasmani, Kesehatan, dan Rekreasi, 1 (72-76), 77.

Wardhani, IGK. (2008). Penelitian Tindakan Kelas. Jakarta: Universitas Terbuka.

Yasbiati, dan Nur, L. (2017). Strategi Pengembangan Fisik Motorik. Tasikmalaya

Universitas Suryakancana, Cianjur.

MS. TAUFIK(2018), Meningkatkan Teknik Dasar Dribbling Sepakbola Melalui Modifikasi Permainan Jurnal Pendidikan Jasmani Kesehatan dan Rekreasi 8 Halaman 2 Penerbit JURNAL MAENPO 
65| Alawiyah Rahmah ${ }^{1}$, Yasbiati $^{2}$, Lutfi Nur ${ }^{3}$, Ervan Kastrena ${ }^{4}$

Peningkatan Kemampuan Gerak Manipulatif Melalui Permainan Bowling Botol

Solihin. (Agustus 2010). "menendang dengan kaki bagian dalam". Artikel, hlm 66.Persatuan Sepakbola Seluruh Indonesia.

(2017). Kurikulum pembinaan sepakbola a seluruh Indonesia. Jakarta selatan : PSSI. Wina Sanjaya, (Jakarta 2011). "perencanaan dan desain system pembelajaran". Artikel, hlm 21 